\title{
Effect of Dietary Phosphorus on Performance of Lactating Dairy Cows: Milk Production and Cow Health*
}

\author{
H. Lopez, ${ }^{1}$ F. D. Kanitz, ${ }^{2}$ V. R. Moreira, ${ }^{1}$ M. C. Wiltbank, ${ }^{1}$ and L. D. Satter ${ }^{1,2}$ \\ ${ }^{1}$ Department of Dairy Science, University of Wisconsin, \\ ${ }^{2}$ U.S. Dairy Forage Research Center, \\ USDA-Agricultural Research Service, \\ Madison 53706
}

\begin{abstract}
The objective of this study was to measure cow response to feeding of two dietary concentrations of $\mathrm{P}$, one of which was close to recent National Research Council requirements, and the other of which was well in excess of the requirement. Diets containing 0.37 or $0.57 \% \mathrm{P}$ (dry basis) were fed to Holstein cows for the first $165 \mathrm{~d}$ of lactation, and occasionally longer until cows were confirmed pregnant approximately $60 \mathrm{~d}$ after insemination. At calving, cows were randomly assigned to experimental diets. The number of cows completing a minimum of $165 \mathrm{~d}$ of lactation was 123 for the 0.37 and 124 for the $0.57 \% \mathrm{P}$ groups. Cows were housed in a stanchion barn and fed one of two transition diets, each formulated to contain one of the $\mathrm{P}$ treatments for the first $3 \mathrm{wk}$ of lactation, and then cows were moved to a free-stall barn where the experimental diets were group fed. Milk production, milk fat, and milk protein averaged $35.1 \mathrm{~kg} / \mathrm{d}, 3.92 \%$, and $2.90 \%$ for the $0.37 \% \mathrm{P}$ diet, and $34.9 \mathrm{~kg} / \mathrm{d}, 3.98 \%$, and $2.91 \%$ for the $0.57 \% \mathrm{P}$ diet. None of these measures were different between treatments. Blood serum P concentrations on d 50 and 100 of lactation averaged 6.1 and $6.2 \mathrm{mg} / \mathrm{dL}$ for the $0.37 \% \mathrm{P}$ diet, and 6.8 and $6.9 \mathrm{mg} / \mathrm{dL}$ for the $0.57 \% \mathrm{P}$ diet. No treatment differences were detected in milk production, cow health, or body condition score.
\end{abstract}

(Key words: dairy cow, milk production, phosphorus requirement)

\section{INTRODUCTION}

Overfeeding of $\mathrm{P}$ is costly and increases the risk of environmental damage through eutrophication of lakes and streams (Rotz et al., 2002). Once the $\mathrm{P}$ require-

Received April 2, 2003.

Accepted August 7, 2003.

Corresponding author: L. D. Satter; e-mail: lsatter@dfrc.wisc.edu.

*Trade names and the names of commercial companies are used in this report to provide specific information. Mention of a trade name or manufacturer does not constitute a guarantee or warranty of the product by the USDA or an endorsement over products not mentioned. ments of the cow are met, most excess dietary $\mathrm{P}$ is excreted in the manure, primarily in the feces (Wu et al., 2000, 2001). This excess $P$ may accumulate in the environment through recycling of manure to land as fertilizer for crop production. Surface runoff from soils high in $\mathrm{P}$ content can contain sufficient $\mathrm{P}$ to stimulate algae growth and eutrophication of surface waters (An and Park, 2002; Mainston and Parr, 2002). Since fecal $\mathrm{P}$ excretion increases linearly as $\mathrm{P}$ intake is increased above the requirement, close monitoring of dietary $\mathrm{P}$ is required to minimize risk of environmental damage caused by excessive $\mathrm{P}$ excretion in the feces (Knowlton and Herbein, 2002; Wu et al., 2000, 2001).

Several surveys in the United States (Bertrand et al., 1999; Sansinena et al., 1999) indicate that dairy producers feed $\mathrm{P}$ at concentrations that are 15 to $20 \%$ in excess of NRC (2001) requirements. Eliminating the excess supplemental $\mathrm{P}$ from dairy diets may result in as much as 25 to $30 \%$ reduction of $\mathrm{P}$ content of manure, and a savings of $\$ 10$ to 15 per cow per year in $\mathrm{P}$ supplementation costs (Wu et al., 2000).

Anecdotal evidence suggests that dairy producers have reduced dietary $\mathrm{P}$ a modest amount since 1999, but there continues to be resistance to lowering of dietary $\mathrm{P}$ down to NRC (2001) requirements. Part of the resistance is due to uncertainty about how much of a safety margin should be provided above the minimum needed to avoid deficiency symptoms. Evidence is now available (Brintrup et al., 1993; Valk and Sebek, 1999; Wu et al., 2001) from long-term lactation studies suggesting that moderate to high-producing dairy cows need a minimum of approximately $0.30 \%$ dietary $\mathrm{P}$ because deficiency symptoms may begin to appear at this dietary concentration. If NRC (2001) requirements are used as a feeding guideline $(0.32$ to $0.38 \%$ dietary $\mathrm{P}$, depending on level of milk production) then a 10 to $20 \%$ margin of safety would be assured.

Perhaps a more often cited reason for not reducing $P$ to NRC (2001) requirement amounts is concern about reproductive performance of cows fed reduced dietary P. While there is ample evidence (Theiler and Green, 1932; Hignett and Hignett, 1951) that feeding of ex- 
tremely low dietary $\mathrm{P}$ can impair reproductive performance, there is no suggestion in the literature that feeding P in excess of current NRC (2001) recommendations will improve reproductive performance.

The majority of studies dealing with $\mathrm{P}$ feeding and reproductive performance have lacked power of test to detect treatment responses. Large numbers of animals are needed to draw conclusions regarding reproductive performance. The objective of this study was to measure milk production, blood serum $P$ concentrations, and incidence of health problems with a large number of cows fed $\mathrm{P}$ either in amounts close to the NRC (2001) requirement or well in excess of the requirement. This paper reports results pertaining to milk production and animal health, and an accompanying paper (Lopez et al., 2004) reports results related to reproductive performance.

\section{MATERIALS AND METHODS}

A total of 267 lactating Holstein cows started the experiment. They were assigned at calving to diets containing either 0.37 (recommended) or $0.57 \% \mathrm{P}$ (excess) on a DM basis. Since milk production is the focus of this report, cows not completing at least 165 DIM were deleted from this part of the overall study. A total of 20 cows (11 and 9 cows for the recommended and excess $\mathrm{P}$ groups, respectively) were removed from the experiment due to significant health problems or to routine culling from the herd before completing 165 DIM. A total of 128 primiparous and 119 multiparous cows completed this phase of the study. With only rare exceptions, primiparous and multiparous cows were fed the same diet for the 4 wk preceding calving.

The $0.37 \% \mathrm{P}$ treatment corresponded closely to the NRC (2001) requirement for cows at the milk production level reported in this experiment, and the $0.57 \%$ $\mathrm{P}$ treatment provided $\mathrm{P}$ in considerable excess of the NRC (2001) requirement. During the first 3 wk of lactation cows were fed transition diets containing either 0.37 or $0.57 \% \mathrm{P}$ (DM basis). Starting at the beginning of wk 4 and continuing until the end of the trial, cows were fed lactation diets containing the corresponding recommended $(0.37 \%)$ or excess $\mathrm{P}(0.57 \%)$. Treatment diets were nearly identical, except that the $0.37 \% \mathrm{P}$ diet was formulated without supplemental P. The $0.57 \% \mathrm{P}$ diet was obtained by adding monosodium phosphate. Several forage sources were used throughout the $18 \mathrm{mo}$ of this study, and, in response to changes in nutrient composition of forages, appropriate changes were made in the ration formulation to maintain diet energy and protein levels. Most concentrate ingredients (soybean meal, vit/min mix, salt, limestone, sodium bicarbonate, magnesium oxide, and monosodium phosphate) were incorporated into the ration as premixes for 9 of the 12 mo that transition diets were fed and for 12 of the 17.5 mo that lactation diets were fed. For the rest of the experimental period, rations were mixed daily using individual ingredients. The diet ingredients and the minimum and maximum amount used during the study, expressed as a percentage of diet DM, are shown in Table 1.

Cows were housed in a tie-stall barn during the first $3 \mathrm{wk}$ of lactation and offered a TMR ad libitum (5 to $10 \%$ refusal) and approximately $1.7 \mathrm{~kg}$ of alfalfa hay (as fed) once daily. Actual amounts of TMR offered and refused by individual animals were recorded daily to monitor feed intake during the first $3 \mathrm{wk}$ of lactation. Cows were moved to a free-stall barn after wk 3 of lactation and fed as 2 groups once daily. Fed consumption was not measured following the first 3 wk of lactation. A trace mineral/salt mix containing 94 to $96 \%$ salt and at least $5500 \mathrm{mg} / \mathrm{kg}$ of Zn, $5500 \mathrm{mg} / \mathrm{kg}$ of Mn, 1400 $\mathrm{mg} / \mathrm{kg}$ of Cu, $3450 \mathrm{mg} / \mathrm{kg}$ of Fe, $80 \mathrm{mg} / \mathrm{kg}$ of I, $20 \mathrm{mg} /$ $\mathrm{kg}$ of Co, and $60 \mathrm{mg} / \mathrm{kg}$ of Se (Vita Plus Corp., Madison, WI) was available ad libitum at all times in both treatment pens. All cows in the study were scored for body condition once per month for the duration of their tenure on the experiment, since cow reproductive measurements continued beyond 165 DIM for some cows (Lopez et al., 2004). Scoring was normally done by 3 individuals using a 5-point scale with 1 as very thin and 5 as obese (Wildman et al., 1982), and the mean of the 3 scores was recorded. Body condition scoring was done for all cows on a given day, so scores do not coincide with a selected day or week of lactation. Body weight measurements were not made in this study. Health problems were considered as conditions requiring medical treatment and were recorded as days on which treatment was given. Treatment days separated by more than 6 d were considered separate occurrences. Alfalfa silage, corn silage, TMR and orts were sampled daily, frozen, and composited weekly for chemical analysis. Once weekly samples of alfalfa silage, corn silage, and high moisture shelled corn were used for DM determination by oven drying at $60^{\circ} \mathrm{C}$ for $48 \mathrm{~h}$. These DM measurements were used for weekly adjustments in diet formulations to accommodate changes in DM content of the silages. Concentrates (roasted soybeans, molasses, yeast, soybean meal, and premixes), alfalfa hay, and minerals were sampled monthly.

All dried feed samples were ground through a Wiley mill with a 1-mm screen (Arthur H. Thomas, Philadelphia, PA). Monthly samples of ground concentrate, alfalfa hay, premixes, minerals, and selected weekly composite silage samples ( 1 to 7 per silo) were analyzed for $\mathrm{P}$. The monthly concentrate samples were ground and composited every 3 mo. These composite samples, 
Table 1. Formulation of TMR containing recommended $(0.37 \%)$ or excess $(0.57 \%)$ dietary P.

\begin{tabular}{|c|c|c|c|c|}
\hline \multirow[b]{2}{*}{ Ingredient } & \multicolumn{2}{|c|}{$0.37 \% \mathrm{P}$} & \multicolumn{2}{|c|}{$0.57 \%$} \\
\hline & $\begin{array}{l}\text { First } 3 \text { wk } \\
\text { of lactation }^{1}\end{array}$ & $\begin{array}{l}\text { Remainder } \\
\text { of lactation }\end{array}$ & $\begin{array}{l}\text { First } 3 \mathrm{wk} \\
\text { of lactation }^{1}\end{array}$ & $\begin{array}{l}\text { Remainder } \\
\text { of lactation }\end{array}$ \\
\hline & & $(\% 0$ & DM) & \\
\hline Alfalfa silage & $20.9-32.0$ & $21.5-29.0$ & $21.0-32.0$ & $24.5-29.0$ \\
\hline Corn silage & $27.5-38.4$ & $24.5-29.0$ & $27.2-38.4$ & $24.5-29.0$ \\
\hline High moisture shelled corn & $12.9-20.2$ & $21.0-26.0$ & $13.9-20.2$ & $20.3-25.5$ \\
\hline Roasted soybeans & $12.6-15.0$ & $13.5-14.6$ & $12.6-15.6$ & $13.5-14.6$ \\
\hline Linted whole cottonseed & - & $0.0-4.0$ & - & $0.0-4.0$ \\
\hline Soybean meal & $5.2-5.8$ & $5.0-5.2$ & $5.3-5.8$ & $5.0-5.3$ \\
\hline Dried molasses $^{2}$ & $3.0-3.5$ & - & $3.0-3.5$ & - \\
\hline Salt & $0.26-0.40$ & $0.26-0.30$ & $0.27-0.40$ & $0.27-0.30$ \\
\hline Limestone & $0.42-0.58$ & $0.42-0.50$ & $0.43-0.58$ & $0.43-0.50$ \\
\hline Sodium bicarbonate & $0.42-0.58$ & $0.42-0.50$ & $0.43-0.58$ & $0.43-0.50$ \\
\hline Magnesium oxide & $0.08-0.10$ & $0.08-0.10$ & $0.09-0.11$ & $0.09-0.10$ \\
\hline Vitamin/Trace mineral mix $^{3}$ & $0.08-0.10$ & $0.08-0.10$ & $0.09-0.10$ & $0.09-0.10$ \\
\hline Monosodium phosphate & - & - & $0.60-0.82$ & $0.60-0.70$ \\
\hline Yeast $^{4}$ & 0.24 & - & 0.24 & - \\
\hline
\end{tabular}

${ }^{1}$ One block of alfalfa hay per day $(1.7 \mathrm{~kg}$ as fed) was given to each cow for the first $3 \mathrm{wk}$.

${ }^{2}$ Molasses source : Kaptain Kid Dried Molasses, Harvest Brand Inc., Pittsburgh, KS.

${ }^{3}$ Vit/min mix = VIT TM PAK, Professional Products, Inc. Prairie du Sac, WI. (Ca 18.4-20.4\%, Se > 320 $\mathrm{ppm}$, Vit A > 7,084,000 IU/kg, Vit D-3 > 2,200,000 IU/kg, Vit E > 17,600 IU/kg, and S, 5.51\%; Co, 0.04\% ; Fe, 2.40\% ; Zn, 6.19\% ; Cu,1.33\% ; Mn, 5.10\% ; I, 0.10\%).

${ }^{4}$ Yeast $=$ Diamond V XP Yeast Culture, Diamond V Mills Inc., Cedar Rapids, IA.

ground 4-wk composite premix samples, and ground weekly silage samples were analyzed for $\mathrm{DM}\left(105^{\circ} \mathrm{C}\right)$, CP (LECO FP-2000 Nitrogen Analyzer, Leco Instruments, Inc., St. Joseph, MI), NDF (heat-stable amylase and $\mathrm{Na}_{2} \mathrm{SO}_{3}$ were used), and $\mathrm{ADF}$ (Robertson and Van Soest, 1981). The ANKOM ${ }^{200}$ Fiber Analyzer incubator (ANKOM Technology, Fairport, NY) was used for sequential NDF and ADF analyses.

For analysis of $\mathrm{P}$, ground samples were ashed and processed as described by Nelson and Satter (1992), but the amount of concentrated $\mathrm{HCl}$ was increased from 10 to $15 \mathrm{ml}$. Samples were analyzed for P content by direct current plasma emission spectroscopy by adapting the procedure described by Combs and Satter (1992). A certified commercial P solution (VHG Labs, Inc., Man- chester, $\mathrm{NH}$ ) was used as a calibration standard. Accuracy of the analysis was assured by referring to additional commercial standards (Standard Reference Material 1570a, spinach leaves, and 8436, durum wheat flour; National Institute of Standards and Technology, Gaithersburg, MD).

Results of chemical analyses of feed are reported based on DM measurements made at $105^{\circ} \mathrm{C}$. Weekly composite alfalfa silage and corn silage samples were selected for analysis for the period of time that a particular silage was fed. Eleven different alfalfa silages and nine different corn silages were used during the course of this experiment. Each silo was sampled different times (from 1 to 7 samples) and means of these samples were used to calculate nutrient composition of the diet

Table 2. Chemical composition of TMR containing recommended $(0.37 \%)$ or excess $(0.57 \%)$ dietary $\mathrm{P}^{1}$.

\begin{tabular}{|c|c|c|c|c|c|c|c|c|}
\hline \multirow[b]{3}{*}{ Item } & \multicolumn{4}{|c|}{ Transition diets $^{2}$} & \multicolumn{4}{|c|}{ Lactation $\operatorname{diets}^{3}$} \\
\hline & \multicolumn{2}{|c|}{$0.37 \% \mathrm{P}$} & \multicolumn{2}{|c|}{$0.57 \% \mathrm{P}$} & \multicolumn{2}{|c|}{$0.37 \% \mathrm{P}$} & \multicolumn{2}{|c|}{$0.57 \% \mathrm{P}$} \\
\hline & Mean & SEM & Mean & SEM & Mean & SEM & Mean & SEM \\
\hline $\mathrm{n}^{4}$ & 12 & & 11 & & 15 & & 15 & \\
\hline $\mathrm{CP}$ & 18.5 & 0.25 & 18.3 & 0.12 & 18.9 & 0.09 & 18.8 & 0.09 \\
\hline NDF & 28.6 & 0.74 & 30.0 & 0.39 & 30.5 & 0.29 & 30.4 & 0.30 \\
\hline $\mathrm{ADF}$ & 17.5 & 0.49 & 18.6 & 0.35 & 18.4 & 0.24 & 18.4 & 0.24 \\
\hline Phosphorus & 0.35 & 0.01 & 0.57 & 0.01 & 0.37 & 0.01 & 0.58 & 0.01 \\
\hline
\end{tabular}

${ }^{1}$ Chemical composition based on analysis of individual diet ingredients and pre-mixes.

${ }^{2} \mathrm{Fed}$ for the first $3 \mathrm{wk}$ postpartum.

${ }^{3} \mathrm{Fed}$ from wk 4 postpartum, and on to the end of the experiment.

${ }^{4} \mathrm{n}=$ number of ration formulations, based on change in silage or animal performance. 
Table 3. Chemical composition of forages used in TMR.

\begin{tabular}{|c|c|c|c|c|c|c|}
\hline & $\mathrm{n}^{1}$ & $\% \mathrm{DM}$ & $\mathrm{CP}$ & $\mathrm{NDF}$ & $\mathrm{ADF}$ & $\mathrm{P}$ \\
\hline Forages & & \multicolumn{5}{|c|}{$(\%$ of $\mathrm{DM})$} \\
\hline Alfalfa hay & & & & & & \\
\hline $\begin{array}{l}\text { Average } \\
\text { SEM } \\
\text { Alfalfa silage }\end{array}$ & 12 & $\begin{array}{l}89 \\
0.04\end{array}$ & $\begin{array}{c}20.5 \\
0.06\end{array}$ & $\begin{array}{c}44.5 \\
0.20\end{array}$ & $\begin{array}{c}35.6 \\
0.19\end{array}$ & $\begin{array}{l}0.31 \\
0.01\end{array}$ \\
\hline $\begin{array}{l}\text { Average } \\
\text { SEM }\end{array}$ & 11 & $\begin{array}{c}44.6 \\
1.80\end{array}$ & $\begin{array}{c}22.8 \\
0.53\end{array}$ & $\begin{array}{c}41.7 \\
0.97\end{array}$ & $\begin{array}{c}34.0 \\
0.94\end{array}$ & $\begin{array}{l}0.33 \\
0.01\end{array}$ \\
\hline Corn silage & & & & & & \\
\hline Average & 9 & 36.2 & 7.2 & 38.8 & 22.6 & 0.22 \\
\hline SEM & & 1.46 & 0.24 & 0.75 & 1.08 & 0.01 \\
\hline
\end{tabular}

${ }^{1} \mathrm{n}=$ individual samples of hay and number of different silages (17 samples analyzed/silo).

ingredients. Nutrient content of the TMR was computed from the average nutrient content of the individual diet ingredients analyzed as indicated above.

Cows were milked twice daily (0500 and $1700 \mathrm{~h}$ ), and milk yields were recorded at each milking until 165 DIM. All cows were administered bST (Posilac; Monsanto Co., St. Louis, MO) every $2 \mathrm{wk}$, beginning at 63 to 70 DIM. Milk samples were collected monthly from a.m. and p.m. consecutive milkings, and sent to AgSource Cooperative Services (Menomonie, WI) for analyses of fat and protein by near-infrared spectroscopy (Foss MilkoScan 4000; Foss Technology, Eden Prairie, MN) and SCC by fluorescence (Fossmatic 5000; Foss Technology).

Blood samples $(\sim 10 \mathrm{ml})$ were collected via coccygeal venipuncture using evacuated tubes (Vacutainer; Becton-Dickinson, Rutherford, NJ) on approximately 50 and 100 DIM, and allowed to clot before chilling. Samples were centrifuged at $1600 \times \mathrm{g}$ for $15 \mathrm{~min}$ and serum was collected and stored refrigerated at $4^{\circ} \mathrm{C}$ in $10-\mathrm{ml}$ plastic scintillation vials until analyzed. Serum was analyzed for inorganic $\mathrm{P}\left(\mathrm{P}_{\mathrm{i}}\right)$ by the Marshfield Laboratories (Marshfield, WI) using the molybdovanadate colorimetric procedure (AOAC, 1980). The protocol used in this study was approved by the Animal Care Commit-

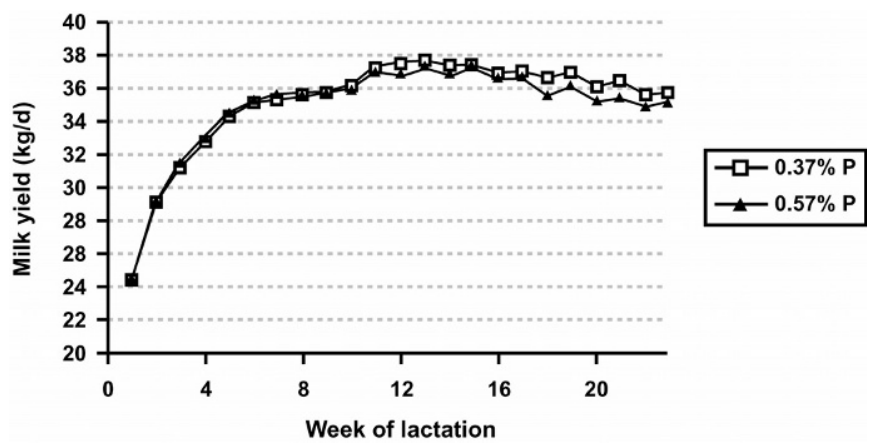

Figure 1. Lactation curves for cows fed either $0.37 \%$ or $0.57 \%$ dietary phosphorus.

tee of the College of Agricultural and Life Sciences, University of Wisconsin, Madison.

Daily milk yield was reduced to weekly means. These means, data on BCS, and data on milk component percentages were analyzed by the MIXED procedure of SAS using both random and repeat measures statements with autoregressive-1 (ar-1) as the covariate structure for repeated measurements and the model Y $=$ treatment time treatment $\times$ time (Littell et al., 1998; SAS, 1996). Incidence of health problems was analyzed for treatment effects using the FREQ procedure of SAS with chi-square and Fisher's exact tests (SAS, 1996). Data on serum P concentrations were compared by Student's $t$-test.

\section{RESULTS AND DISCUSSION}

The chemical composition (DM basis; means and SEM) of the TMR throughout the 18-mo duration of the experiment is in Table 2. The $\mathrm{P}$ content of the recommended diet corresponded closely to what the National Research Council (NRC, 2001) considers to be the requirement for lactating cows with milk production similar to that of cows used in this experiment. The current NRC recommendations for early to midlactation (90

Table 4. Least square means and standard errors for milk production, and milk components of lactating cows receiving $0.37 \%$ or $0.57 \%$ dietary P.

\begin{tabular}{|c|c|c|c|c|c|}
\hline \multirow[b]{3}{*}{ Item } & \multicolumn{4}{|c|}{ Dietary P content $(\%)$} & \multirow[b]{3}{*}{$P$} \\
\hline & \multicolumn{2}{|c|}{0.37} & \multicolumn{2}{|c|}{0.57} & \\
\hline & Mean & SEM & Mean & SEM & \\
\hline Number of cows & 123 & & 124 & & \\
\hline Milk yield ${ }^{1}$ (kg/day) & 35.1 & 0.52 & 34.9 & 0.52 & 0.81 \\
\hline $3.5 \% \mathrm{FCM}^{1}$ (kg/day) & 36.8 & 0.65 & 36.9 & 0.64 & 0.87 \\
\hline Milk fat ${ }^{1}(\%)$ & 3.92 & 0.04 & 3.98 & 0.04 & 0.32 \\
\hline Milk protein ${ }^{1}(\%)$ & 2.90 & 0.02 & 2.91 & 0.02 & 0.82 \\
\hline $\operatorname{SCC}^{1}\left(10^{3} / \mathrm{ml}\right)$ & 319 & 39.3 & 366 & 39.1 & 0.39 \\
\hline
\end{tabular}

\footnotetext{
${ }^{1}$ First $165 \mathrm{~d}$ of lactation.
} 
Table 5. Summary from published studies of milk production response to dietary phosphorus content.

\begin{tabular}{|c|c|c|c|c|c|c|}
\hline \multirow{2}{*}{$\begin{array}{l}\text { Number of cows } \\
\text { per treatment }\end{array}$} & \multirow{2}{*}{$\begin{array}{l}\text { Duration } \\
\text { of study }\end{array}$} & \multicolumn{2}{|c|}{$\begin{array}{c}\text { Dietary P } \\
\text { \% of diet DM }\end{array}$} & \multicolumn{2}{|c|}{$\begin{array}{l}\text { Milk yield } \\
\text { kg/d }\end{array}$} & \multirow[b]{2}{*}{$P$} \\
\hline & & Low $\mathrm{P}$ & High P & Low $\mathrm{P}$ & High $\mathrm{P}$ & \\
\hline $20^{1}$ & $10 \mathrm{mo}$ & 0.30 & 0.54 & 28.0 & 30.0 & $>0.05$ \\
\hline $26^{2}$ & 2 complete lactations & 0.33 & 0.39 & 25.4 & 24.5 & $>0.05$ \\
\hline $23^{3}$ & $12 \mathrm{wk}$ midlactation & 0.39 & 0.65 & 23.9 & 24.4 & 0.90 \\
\hline $6-8^{4}$ & wk $17-23$ & 0.28 & 0.34 & 24.1 & 24.5 & $>0.10$ \\
\hline $6-8^{4}$ & wk 2-31 & 0.28 & 0.34 & 34.1 & 33.1 & $>0.10$ \\
\hline $9^{5}$ & complete lactation & 0.40 & 0.49 & 36.5 & 36.2 & $>0.10$ \\
\hline $21^{6}$ & complete lactation & $0.31-0.38$ & $0.44-0.48$ & 29.6 & 28.8 & 0.50 \\
\hline \multirow[t]{2}{*}{$26^{6}$} & complete lactation & $0.31-0.38$ & $0.44-0.48$ & 32.0 & 32.1 & 0.94 \\
\hline & Mean & 0.33 & 0.46 & 29.2 & 29.2 & - \\
\hline
\end{tabular}

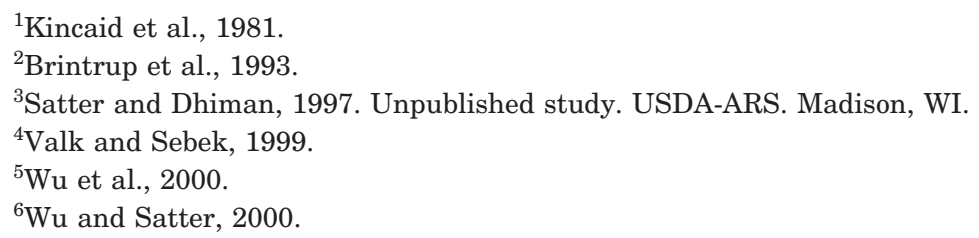

DIM) diets are $0.36 \% \mathrm{P}$ (DM basis) for cows milking 45 $\mathrm{kg} / \mathrm{d}$ and $0.35 \% \mathrm{P}$ for cows milking $35 \mathrm{~kg} / \mathrm{d}$. The NRC (2001) suggests feeding a slightly higher dietary P concentration during the first several weeks of lactation compared with later lactation in order to compensate for the lag in feed intake relative to milk production in the first weeks following parturition. However, the NRC (2001) does not take into account P mobilized from bone during early lactation. Estimates from beef cattle (Ternouth, 1990) suggest that a dairy cow weighing approximately $600 \mathrm{~kg}$ could mobilize 600 to $1000 \mathrm{~g}$ of $\mathrm{P}$ during the first few weeks of lactation. The supply of mobilized bone $\mathrm{P}$ could easily replace the need for an elevated concentration of $\mathrm{P}$ in early lactation diets.

The term "recommended" is used in place of "required" for the $0.37 \% \mathrm{P}$ treatment because the authors believe the NRC (2001) requirement values actually provide for a reasonable margin of safety. Recent experiments (Aguerre et al., 2002; Pfeffer, personal commu-

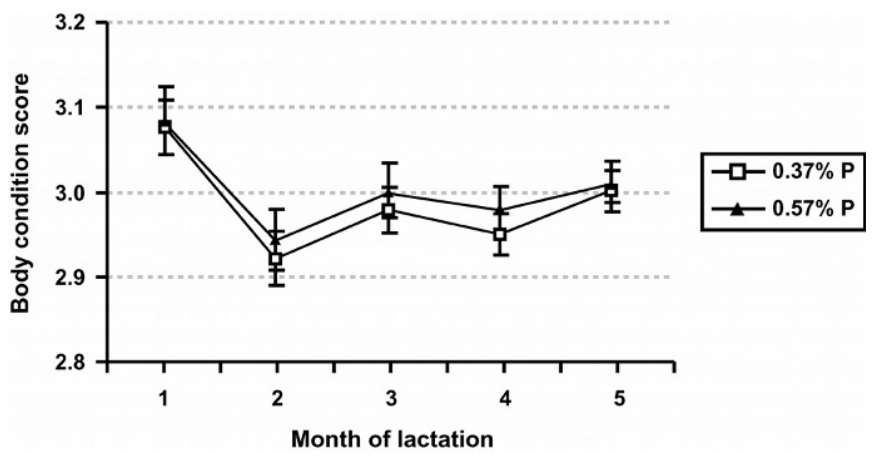

Figure 2. Body condition scores (range 1 to 5 ) for cows fed either $0.37 \%$ or $0.57 \%$ dietary phosphorus. nication, 2003) suggest that the true digestibility and availability of $\mathrm{P}$ in concentrates is higher (72 to $>90 \%$ ) than the value of $70 \%$ used by NRC (2001). Long-term lactation experiments (Valk and Sebek, 1999; Wu et al., 2001) with average- to high-producing cows also suggest that $\mathrm{P}$ deficiency symptoms are not likely to be observed until dietary $\mathrm{P}$ concentration is reduced to approximately $0.31 \%$ of diet DM. Therefore, a dietary $\mathrm{P}$ concentration of 0.35 to $0.37 \%$, assuming DMI approximating NRC (2001) values, should provide sufficient $\mathrm{P}$ to meet the requirement and to provide a reasonable margin of safety.

Table 3 has the chemical composition of the diet ingredients. Alfalfa silage and corn silage were supplied from different silos during the experiment. The mean and SEM of DM, CP, NDF, ADF, and $\mathrm{P}$ are reported for silages and alfalfa hay.

The lactation curves for the 2 treatments are shown in Figure 1. The 2 treatment means essentially overlap each other. Table 4 contains milk production and milk composition information. Table 5 contains a listing of published studies where milk production was measured when cows were fed different amounts of dietary P. The overall means for milk production for the low $(0.33 \%)$ and high $\mathrm{P}(0.46 \%)$ treatment groups were both 29.2 $\mathrm{kg} / \mathrm{d}$.

Milk composition was not affected by dietary $\mathrm{P}$ content. There is no evidence in the literature suggesting that fat content of milk is influenced by feeding $\mathrm{P}$ in excess of NRC (2001) requirements. There have been reports of reduced protein content of milk with low dietary P (De Boer et al., 1981; Call et al., 1987; Wu and Satter, 2000), but the majority of studies (Valk and Sebek, 1999; Wu et al., 2000, 2001) have shown no 
Table 6. Mean inorganic $\mathrm{P}$ content $(\mathrm{mg} / \mathrm{dl})$ of blood serum from lactating dairy cows at 50 or $100 \mathrm{~d}$ postpartum while receiving recommended $(0.37 \%)$ or excess $(0.57 \%)$ dietary $\mathrm{P}$.

\begin{tabular}{lllllll}
\hline & \multicolumn{3}{c}{$0.37 \% \mathrm{P}$} & & \multicolumn{3}{c}{$0.57 \% \mathrm{P}$} & \\
\cline { 2 - 3 } Serum P $(\mathrm{mg} / \mathrm{dl})$ & Average & SEM & & Average & SEM & $P$ \\
\hline 50 d postpartum & 6.1 & 0.1 & 6.8 & 0.1 & $<0.001$ \\
100 d postpartum & 6.2 & 0.1 & 6.9 & 0.1 & $<0.001$ \\
\hline
\end{tabular}

*Normal range for bovine serum inorganic $\mathrm{P}=4.4$ to $9.2 \mathrm{mg} / \mathrm{dl}$.

difference in concentration of milk protein due to dietary $\mathrm{P}$ content. Since P is part of the casein micelle (Jenness, 1985), blood serum P concentration could influence milk protein content. However, in this study, milk protein content for the 2 treatments was virtually identical.

Mean BCS from monthly measurements while cows were on the experiment averaged 3.0 for both treatments groups. The monthly BCS are shown in Figure 2. Mean concentrations of $P$ in serum are shown in Table 6. Serum inorganic $\mathrm{P}\left(\mathrm{P}_{\mathrm{i}}\right)$ averaged 6.1 and 6.2 $\mathrm{mg} / \mathrm{dL}$ at 50 and $100 \mathrm{DIM}$ for the $0.37 \% \mathrm{P}$ treatment and 6.8 and $6.9 \mathrm{mg} / \mathrm{dL}$ at comparable sampling times for the $0.57 \% \mathrm{P}$ treatment. These values are within the normal range ( 4.4 to $9.2 \mathrm{mg} / \mathrm{dL}$ ) typically seen in lactating cows (Forar et al., 1982), and correspond to previously reported serum $\mathrm{P}_{\mathrm{i}}$ concentrations of 6.1 and $6.5 \mathrm{mg} / \mathrm{dL}$ in cows fed 0.39 and $0.47 \%$ dietary $\mathrm{P}$ (Wu et al., 2001).

The recorded health problems indicated no apparent association with dietary P content (Table 7). Most studies of dietary $\mathrm{P}$ requirements of dairy cows have not had

Table 7. Occurrences of health problems in lactating dairy cows receiving recommended $(0.37 \%)$ or excess $(0.57 \%)$ phosphorus in the diet. ${ }^{1,2}$

\begin{tabular}{llll}
\hline Problem & $0.37 \% \mathrm{P}$ & $0.57 \% \mathrm{P}$ & $P$ \\
\hline Mastitis & 44 & 47 & 0.73 \\
Foot/Leg & 24 & 27 & 0.66 \\
Elevated temperature & 21 & 17 & 0.46 \\
Retained Placenta & 21 & 14 & 0.19 \\
Pyometra & 8 & 10 & 0.76 \\
Displaced abomasum & 8 & 8 & 0.99 \\
Udder edema & 2 & 6 & 0.28 \\
Diarrhea & 2 & 5 & 0.45 \\
Eye inflammation & 0 & 6 & 0.03 \\
Ketosis & 2 & 3 & 0.99 \\
Respiratory infection & 2 & 2 & 0.99 \\
Teat injury & 2 & 1 & 0.62 \\
Milk fever & 3 & 0 & 0.12 \\
Bloat & 1 & 0 & 0.50 \\
Downer cow & 0 & 1 & 0.99 \\
Dystocia & 1 & 0 & 0.50 \\
\hline
\end{tabular}

${ }^{1}$ Health problems were recorded as days on which treatment was given. Treatment days with $>6 \mathrm{~d}$ between them were considered separate occurrences.

${ }^{2}$ Total number of cows in the experiment was 123 for $0.37 \% \mathrm{P}$ and 124 for $0.57 \% \mathrm{P}$. sufficient animal numbers to draw conclusions about dietary $\mathrm{P}$ and animal health. There is no evidence in this experiment that feeding $\mathrm{P}$ in excess of the NRC (2001) requirement affects the incidence of health problems.

\section{CONCLUSIONS}

The results of this large lactation study show that feeding $\mathrm{P}$ in excess of $0.37 \%$ of diet DM, an amount corresponding closely to NRC (2001) P requirements, did not affect milk production, milk composition, or animal health. This study, along with other studies reported in the literature, provides abundant evidence that feeding $\mathrm{P}$ in excess of NRC (2001) requirements will not increase milk production.

\section{ACKNOWLEDGMENTS}

The authors thank employees at the US Dairy Forage Research Center farm at Prairie du Sac, WI, for feed preparation and animal care; and Mary Becker, Matias Aguerre, Hendrick Henselmeyer, Zachary Schott, Kathleen Herbert, and Amber Rew for technical support. Appreciation is extended to USDA-CREES National Research Initiative, Agricultural Systems Research Program (Grant \# 9703968) for partial funding of this study.

\section{REFERENCES}

Aguerre, M. J., S. Marcot, H. Henselmeyer, and L. D. Satter. 2002. Availability of phosphorus in dairy diets. J. Dairy Sci. 85(Suppl. 1):18. (Abstr.)

An, K. G., and S. S. Park. 2002. In situ experimental evidence of phosphorus limitation on algal growth in a lake ecosystem. J. Environ. Sci. 37:913-924.

Association of Official Agricultural Chemists. 1980. Official Method of Analysis. 13th ed. AOAC, Washington, DC.

Bertrand, J. A., J. C. Fleck, and J. C. McConnell. 1999. Phosphorus intake and excretion on South Carolina dairy farms. Prof. Anim. Sci. 15:264-267.

Brintrup, R., T. Mooren, U. Meyer, H. Spiekers, and E. Pfeffer. 1993. Effects of two levels of phosphorus intake on performance and fecal phosphorus excretion of dairy cows. J. Anim. Physiol. Anim. Nutr. 69:29-36.

Call, J. W., J. E. Butcher, J. L. Shupe, R. C. Lamb, R. L. Boman, and A. E. Olson. 1987. Clinical effects of low dietary phosphorus concentrations in feed given to lactating dairy cows. Am. J. Vet. Res. 48:133-136. 
Combs, D. K., and L. D. Satter. 1992. Determination of markers in digesta and feces by direct current plasma emission spectroscopy. J. Dairy Sci. 75:2176-2183.

De Boer, G., J. G. Buchanan-Smith, G. K. Macleod, and J. S. Walton. 1981. Responses of dairy cows fed alfalfa silage supplemented with phosphorus, copper, zinc, and manganese. J. Dairy. Sci. 64:2370-2377.

Forar, F. L., R. K. Kincaid, R. L. Preston, and J. K. Hillers. 1982. Variation of inorganic phosphorus in blood plasma and milk of lactating cows. J. Dairy Sci. 65:760-763.

Hignett, S. L., and P. G. Hignett. 1951. The influence of nutrition on reproductive efficiency in cattle. The effect of calcium and phosphorus intake on the fertility of cows and heifers. Vet. Rec. 63:603-609.

Jenness, R. 1985. Biochemical and nutritional aspects of milk and colostrum. Pages 164-197 in Lactation. B. L. Larson, ed. The Iowa State Univ. Press, Ames.

Kincaid, R. L., J. K. Hillers, and J. D. Cronrath. 1981. Calcium and phosphorus supplementation of rations for lactating cows. J. Dairy Sci. 64:754-758.

Knowlton, K. F., and J. H. Herbein. 2002. Phosphorus partitioning during early lactation in dairy cows fed diets varying in phosphorus content. J. Dairy Sci. 85:1227-1236.

Littell, R. C., P. R. Henry, and C. B. Ammerman. 1998. Statistical analysis of repeat measures data using SAS procedures. J. Anim. Sci. 76:1216-1231.

Lopez, H., F. D. Kanitz, V. Moreira, L. D. Satter, and M. C. Wiltbank. 2004. Reproductive performance of dairy cows fed two concentrations of phosphorus. J. Dairy Sci. 87:146-157.

Mainston, C. P., and W. Parr. 2002. Phosphorus in rivers-ecology and management. Sci. Total Environ. 282-283:25-47.

National Research Council 2001. Nutrient Requirements of Dairy Cattle, 7th rev. ed. Natl. Acad. Sci., Washington, DC.

Nelson, W. F., and L. D. Satter. 1992. Impact of stage of maturity and method of preservation of alfalfa on digestion in lactating dairy cows. J. Dairy Sci. 75:1571-1580.
Robertson, J. B., and P. J. Van Soest. 1981. Page 123 in The Analysis of Dietary Fiber in Foods. W. P. T. Kames and O. Theander, eds. Marcel Dekker, Inc. New York, NY.

Rotz, C. A., A. N. Sharpley, L. D. Satter, W. J. Gburek, and M. A. Sanderson. 2002. Production and feeding strategies for phosphorus management on dairy farms. J. Dairy Sci. 85:3142-3153.

Sansinena, M., L. D. Bunting, S. R. Stokes, and E. R. Jordan. 1999. A survey of trends and rational for phosphorus recommendations among Mid-South nutritionists. Pages 51-54 Proc. Mid-South Ruminant Nutr. Conf., Dallas, TX.

SAS. 1996. User's guide: Statistics, Version 6. SAS Institute, Inc. Cary, NC.

Ternouth, J. H. 1990. Phosphorus and beef production in northern Australia. Phosphorus in cattle-A review. Tropical Grassl. 24:159-169.

Theiler, A., and H. H. Green. 1932. Aphosphorosis in ruminants. Nutr. Abstr. Rev. 1:359-385.

Valk, H., and L. B. J. Sebek. 1999. Influence of longterm feeding of limited amounts of phosphorus on dry matter intake, milk production, and body weight of dairy cows. J. Dairy Sci. 82:2157-2163.

Wildman, E. E., G. M. Jones, P. E. Wagner, R. L. Boman, H. F. Troutt, Jr., and T. N. Lesch. 1982. A dairy cow body condition scoring system and its relationship to selected production characteristics. J Dairy Sci. 65:495-501.

Wu, Z., and L. D. Satter. 2000. Milk production and reproductive performance of dairy cows fed two concentrations of phosphorus for two years. J. Dairy Sci. 83:1052-1063.

Wu, Z., L. D. Satter, A. J. Blohowiak, R. H. Stauffacher, and J. H. Wilson. 2001. Milk production, estimated phosphorus excretion, and bone characteristics of dairy cows fed different amounts of phosphorus for two or three years. J. Dairy Sci. 84:1738-1748.

Wu, Z., L. D. Satter, and R. Sojo. 2000. Milk production, reproductive performance, and fecal excretion of phosphorus by dairy cows fed three amounts of phosphorus. J. Dairy Sci. 83:1028-1041. 